\title{
Increased Expression of the Antiapoptotic Protein MCL1 in Canine Mast Cell Tumors
}

\author{
Yosuke AMAGAI ${ }^{1)}$, Akane TANAKA ${ }^{1,2)^{*}}$, Akira MATSUDA ${ }^{3)}$, Kumiko OIDA ${ }^{1)}$, Kyungsook JUNG ${ }^{1)}$, Sho NISHIKAWA ${ }^{1)}$, \\ Hyosun JANG $^{1)}$, Saori ISHIZAKA ${ }^{1)}$ and Hiroshi MATSUDA ${ }^{1,3)}$ \\ ${ }^{1)}$ Cooperative Major in Advanced Health Science, Graduate School of Bio-Applications and System Engineering, Tokyo University of \\ Agriculture and Technology, Saiwai-cho, Fuchu, Tokyo 183-8509, Japan \\ ${ }^{2)}$ Laboratory of Comparative Animal Medicine, Division of Animal Life Science, Tokyo University of Agriculture and Technology, \\ Saiwai-cho, Fuchu, Tokvo 183-8509, Japan \\ ${ }^{3)}$ Laboratory of Veterinary Molecular Pathology and Therapeutics, Division of Animal Life Science, Tokyo University of Agriculture and \\ Technology, Saiwai-cho, Fuchu, Tokyo 183-8509, Japan
}

(Received 17 January 2013/Accepted 9 February 2013/Published online in J-STAGE 22 February 2013)

ABSTRACT. Myeloid cell leukemia sequence 1 (MCL1) is a potent antiapoptotic protein that plays a critical role in cell survival and drug resistance in various cancers. However, to the best of our knowledge, the role of MCL1 in mast cell tumors (MCTs) has not been investigated in dogs. Here, we detected increased MCL1 expression in MCT cell lines, regardless of the presence of a c-kit mutation. MCL1 expression increased when the cells were exposed to specific inhibitors of mitogen-activated protein kinase or Janus kinase-signaling pathways, thus protecting the cells from apoptosis, but not when KIT or phosphatidylinositol-3 kinase signaling cascades were inhibited. These results indicate that MCL1 expression may contribute to MCT survival and confer drug resistance.

KEY WORDS: mast cell tumor, MCL1.

doi: 10.1292/jvms.13-0025; J. Vet. Med. Sci. 75(7): 971-974, 2013

Myeloid cell leukemia sequence 1 (MCL1) is a member of the Bcl-2 protein family, which plays an antiapoptotic role in various kinds of cells $[2,20]$. It was originally identified in a human leukemia cell line, ML-1, and is currently known as an essential factor responsible for the long lifespan of mature $\mathrm{B}$ and T cells $[11,17]$. MCL1 is also critical in the malignancy and drug resistance of cancer cells [10, 15, 18, 19, 23]. Upregulation of MCL1 is reported to associate with tumor malignancy in breast cancer, ovarian cancer and non-Hodgkin lymphomas $[10,15,18]$. In addition, Wertz et al. [23] have shown that MCL1 downregulation increases the sensitivity of ovarian and breast adenocarcinomas, non-small-cell lung cancer, leukemia and lymphoma to chemotherapy.

As MCL1 contributes to the maintenance of hematopoietic cells, involvement of MCL1 in the survival of malignant hematopoietic cells has been suggested [1, 24, 25]. Aichberger et al. [1] showed that MCL1 is essential for the survival of neoplastic human mast cells, suggesting that it may act as a novel therapeutic target. In dogs, mast cell malignances are known as mast cell tumors (MCTs), which are one of the most commonly encountered neoplasms in veterinary medicine [5]. However, little information is available about the role of MCL1 in canine MCTs. Therefore, we examined the expression and regulatory pathway of MCL1 in canine MCT cell lines.

\footnotetext{
*Correspondence to: Tanaka, A., Cooperative Major in Advanced Health Science, Graduate School of Bio-Applications and System Engineering, Tokyo University of Agriculture and Technology, 3-8-5 Saiwai-cho, Fuchu, Tokyo 183-8509, Japan.

e-mail: akane@cc.tuat.ac.jp

(C)2013 The Japanese Society of Veterinary Science
}

We used 4 MCT cell lines that express different types of wild-type or mutant KIT proteins: HRMC cells expressing wild-type KIT [16], BR cells possessing KIT with a point mutation in its juxtamembrane domain [7], MPT-2 cells expressing KIT with an internal tandem duplication in its juxtamembrane domain [12] and MPT-1.2 cells possessing KIT with an N508I point mutation in its extracellular domain [4]. BR cells were maintained in Dulbecco's modified Eagle's medium (Life Technologies, Gaithersburg, MD, U.S.A.) supplemented with $10 \%$ FBS and antibiotics, while other cell lines were maintained in RPMI 1640 (Life Technologies) supplemented with 10\% FBS (Hyclone, Logan, UT, U.S.A.) and antibiotics. To investigate whether these cell lines express MCL1, western blot analysis was performed. The protocol was performed as described previously [21]. Both first and second antibodies were purchased from Santa Cruz Biotechnology (Santa Cruz, CA, U.S.A.). Because

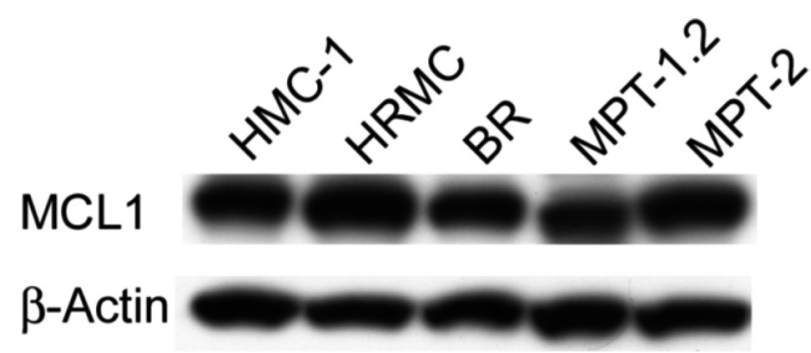

Fig. 1. Detection of MCL1 expression in canine MCT cell lines. The total protein extracted from $10^{5}$ cells was loaded in the lanes of a $12.5 \%$ gel for SDS-PAGE. Human-derived HMC-1 cells were used as the positive control. 

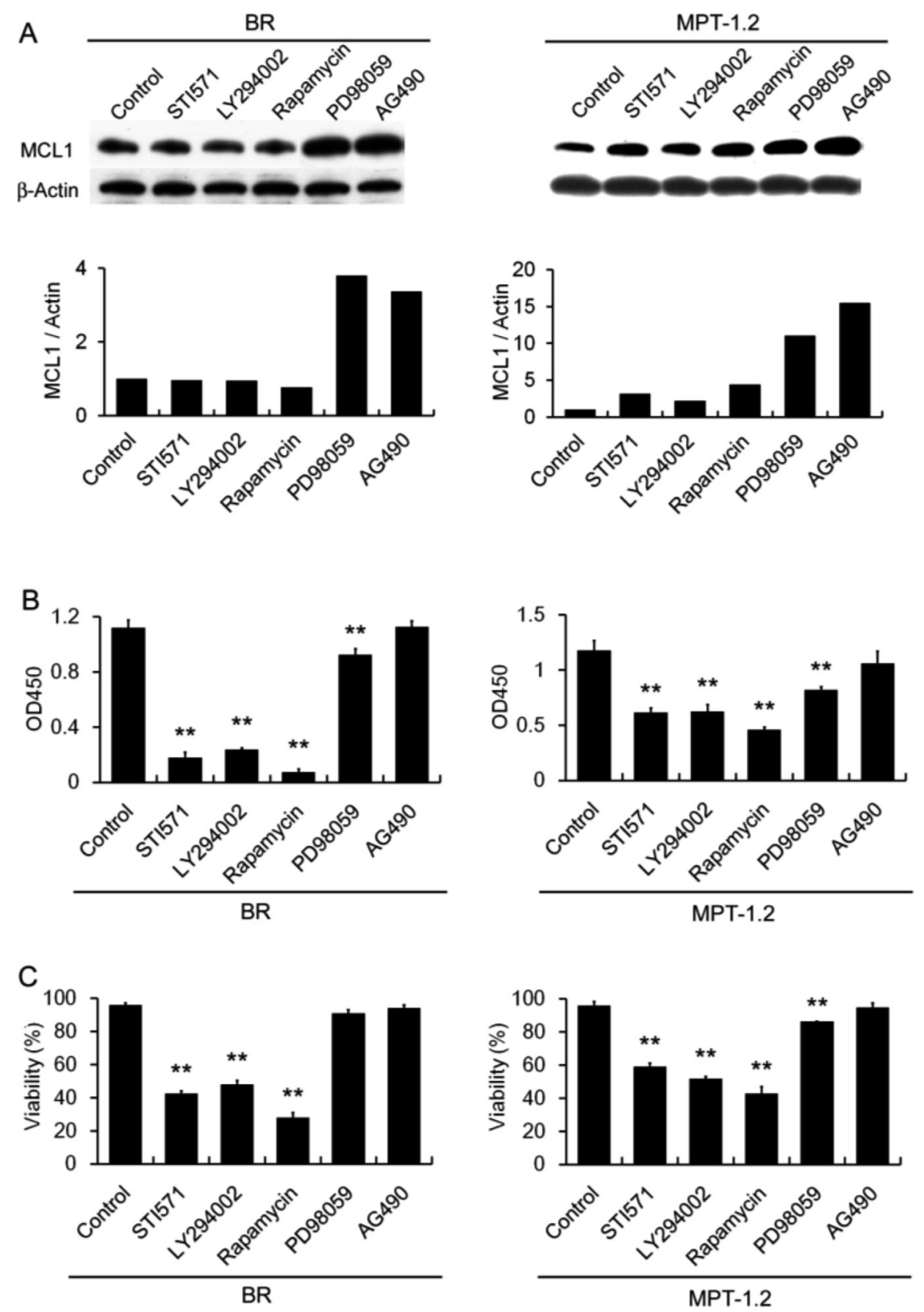

Fig. 2. Effect of each inhibitor on MCL1 expression in neoplastic mast cells.

Changes in MCL1 expression levels for each molecule inhibitor (A). The cells were treated with each inhibitor for $12 \mathrm{hr}$. They were then lysed, and the total protein extracted from $10^{5}$ cells was loaded in the lanes of a $12.5 \%$ gel for SDS-PAGE. The graphs below indicate the relative intensity of the MCL1/ $\beta$-actin ratio. Absorbances of each cell line that was incubated with each inhibitor for $72 \mathrm{hr}$ (B). The experiment was conducted 3 times, and the mean $\pm \mathrm{SD}$ values are shown. ${ }^{* *}, P<0.01$ as compared to the control by Dunnett's test. Viabilities of each cell line that was incubated with each inhibitor for $72 \mathrm{hr}(\mathrm{C})$. The experiment was conducted 3 times, and the mean $\pm \mathrm{SD}$ values are shown. **, $P<0.01$ as compared to the control by Dunnett's test. The concentrations of the reagents in each experiment are as follows: STI571, $100 \mathrm{nM}$; LY294002, $5 \mu \mathrm{M}$; rapamycin, $100 \mathrm{nM}$; PD98059, 10 $\mu \mathrm{M}$; and AG490, $10 \mu \mathrm{M}$.

human-derived HMC-1 mast cells have been reported to express MCL1 [1], they were used as a positive control. As shown in Fig. 1, MCL1 was detected in all the MCT lines that were examined, with expression levels that were as high as those of HMC-1 cells.

We next examined the changes in levels of MCL1 expres- 
sion in all the MCT cell lines under treatment with several molecular inhibitors in order to determine the signaling pathway that mainly regulates MCL1 expression. In addition to the KIT inhibitor STI571 (also known as imatinib mesylate) [9], we evaluated the effect of selective inhibitors that target either phosphoinositide 3-kinase (PI3K) (LY294002) [22], mammalian target of rapamycin (rapamycin) [6], Janus kinase (JAK) 2 (AG490) [13] or mitogen-activated protein kinase (MAPK) (PD98059) [3]. Cell proliferation was evaluated by a 3-(4,5-dimethylthiazol-2-yl)-2,5-diphenyltetrazolium bromide (MTT) assay and a trypan blue dye exclusion test, according to previously described methods [21]. Cells were incubated with fixed concentrations of each reagent for $12 \mathrm{hr}$, and the MCL1 expression levels were determined by western blot analysis. The concentrations were determined according to the $\mathrm{IC}_{50}$ values of each reagent as reported previously [4]. Although STI571, LY294002 and rapamycin suppressed cell proliferation, MCL1 expression in BR cells remained unchanged (Fig. 2A-C). In contrast, both PD98059 and AG490, which did not suppress the proliferation of the cells, dramatically enhanced MCL1 expression in BR cells (Fig. 2A-C). Similar results were seen in MPT-1.2 cells (Fig. 2A-C), MPT-2 cells and HRMC cells (data not shown).

The PI3K pathway has been reported to play a critical role in the regulation of MCL1 expression in humans [13]. Interestingly, the expression levels of MCL1 in the MCT cells were not altered by the PI3K-signaling inhibitors, LY294002 and rapamycin. Therefore, it is likely that the regulatory pathway of MCL1 is different in humans and dogs. Additionally, MCL1 expression increased after suppression of both MAPK and JAK/STAT signaling pathways. The results suggest that MCL1 expression is upregulated by the inactivation of MAPK and/or JAK/STAT signaling pathways in order to rescue the cells from apoptosis. KIT-PI3K pathways directly promote cell proliferation in MCTs independently of anti-apoptotic signals through MCL1. Proliferation and survival of cells are reciprocally regulated [8]. KIT-PI3K pathways promote signals associating with cell proliferation as well as cell survival, which may be suppressed by KITMAPK or KIT-JAK/STAT pathways. Therefore, resistance to apoptosis may be evoked when MAPK or JAK/STAT signals are inhibited, resulting in MCL1 upregulation.

Focusing on the relationship between chemosensitivity and MCL1 expression, MCL1 expression was enhanced by the reagents that did not suppress the growth of each cell line, suggesting that MCL1 contributes to the circumvention of apoptosis against certain cytotoxic agents. In fact, Moulding et al. [14] have reported the importance of MCL1 in circumventing apoptosis in malignant hematopoietic cells through the downregulation of a proapoptotic protein Bak. This finding suggests that MCL1 inhibitors can overcome chemoresistance in MCTs in certain settings.

In conclusion, we detected increased expression of MCL1 in canine MCT cells, raising the possibility of their contribution to the cell survival and drug resistance. Further investigation of the functional role of MCL1 in MCTs may lead to a better understanding of the MCT biology and provide a novel therapeutic approach against canine MCTs.
ACKNOWLEDGMENTS. This work was supported by a Grant-in-Aid for Scientific Research (A) and a Grant-in-Aid for Scientific Research (B) from the Japan Society for the Promotion of Science.

\section{REFERENCES}

1. Aichberger, K. J., Mayerhofer, M., Gleixner, K. V., Krauth, M. T., Gruze, A., Pickl, W. F., Wacheck, V., Selzer, E., Müllauer, L., Agis, H., Sillaber, C. and Valent, P. 2007. Identification of MCL1 as a novel target in neoplastic mast cells in systemic mastocytosis: inhibition of mast cell survival by MCL1 antisense oligonucleotides and synergism with PKC412. Blood 109: 3031-3041. [Medline]

2. Akgul, C. 2009. Mcl-1 is a potential therapeutic target in multiple types of cancer. Cell. Mol. Life Sci. 66: 1326-1336. [Medline] [CrossRef]

3. Alessi, D. R., Cuenda, A., Cohen, P., Dudley, D. T. and Saltiel, A. R. 1995. PD 098059 is a specific inhibitor of the activation of mitogen-activated protein kinase kinase in vitro and in vivo. $J$. Biol. Chem. 270: 489-494. [Medline]

4. Amagai, Y., Tanaka, A., Matsuda, A., Oida, K., Jung, K. and Matsuda, H. The phosphoinositide 3-kinase pathway is crucial for the growth of canine mast cell tumors. J. Vet. Med. (in press).

5. Blackwood, L., Murphy, S., Buracco, P., De Vos, J. P., De Fornel-Thibaud, P., Hirschberger, J., Kessler, M., Pastor, J., Ponce, F., Savary-Bataille, K. and Argyle, D. J. 2012. European consensus document on mast cell tumours in dogs and cats. Vet. Comp. Oncol. 10: e1-e29. [Medline] [CrossRef]

6. Brown, E. J., Albers, M. W., Shin, T. B., Ichikawa, K., Keith, C. T., Lane, W. S. and Schreiber, S. L. 1994. A mammalian protein target by G1-arresting rapamycin-receptor complex. Nature 369: 756-758. [Medline] [CrossRef]

7. Caughey, G. H., Lazarus, S. C., Viro, N. F., Gold, W. M. and Nadel, J. A. 1988. Tryptase and chymase: comparison of extraction and release in two dog mastocytoma lines. Immunology 63 : 339-344. [Medline]

8. Evan, G. I. and Vousden, K. H. 2001. Proliferation, cell cycle and apoptosis in cancer. Nature 411: 342-348. [Medline] [CrossRef]

9. Heinrich, M. C., Griffith, D. J., Druker, B. J., Wait, C. L., Ott, K. A. and Zigler, A. J. 2000. Inhibition of c-kit receptor tyrosine kinase activity by STI 571, a selective tyrosine kinase inhibitor. Blood 96: 925-932. [Medline]

10. Kuramoto, K., Sakai, A., Shigemasa, K., Takimoto, Y., Asaoku, H., Tsujimoto, T., Oda, K., Kimura, A., Uesaka, T., Watanabe, H. and Katoh, O. 2002. High expression of MCL1 gene related to vascular endothelial growth factor is associated with poor outcome in non-Hodgkin's lymphoma. Br. J. Haematol. 116: 158-161. [Medline] [CrossRef]

11. Kozopas, K. M., Yang, T., Buchan, H. L., Zhou, P. and Craig, R. W. 1993. MCL1, a gene expressed in programmed myeloid cell differentiation, has sequence similarity to BCL2. Proc. Natl. Acad. Sci. U. S. A. 90: 3516-3520. [Medline] [CrossRef]

12. Matsuda, A., Tanaka, A., Amagai, Y., Ohmori, K., Nishikawa, S., Xia, Y., Karasawa, K., Okamoto, N., Oida, K., Jang, H. and Matsuda, H. 2011. Glucocorticoid sensitivity depends on expression levels of glucocorticoid receptors in canine neoplastic mast cells. Vet. Immunol. Immunopathol. 144: 321-328. [Medline] [CrossRef]

13. Mills, J. R., Hippo, Y., Robert, F., Chen, S. M., Malina, A., Lin, C. J., Trojahn, U., Wendel, H. G., Charest, A., Bronson, R. T., Kogan, S. C., Nadon, R., Housman, D. E., Lowe, S. W. and Pelletier, J. 2008. mTORC1 promotes survival through trans- 
lational control of Mcl-1. Proc. Natl. Acad. Sci. U. S. A. 105: 10853-10858. [Medline] [CrossRef]

14. Moulding, D. A., Giles, R. V., Spiller, D. G., White, M. R., Tidd, D. M. and Edwards, S. W. 2000. Apoptosis is rapidly triggered by antisense depletion of MCL-1 in differentiating U937 Cells. Blood 96: 1756-1763. [Medline]

15. O’Driscoll, L., Cronin, D., Kennedy, S. M., Purcell, R., Linehan, R., Glynn, S., Larkin, A., Scanlon, K., McDermott, E. W., Hill, A. D., O’Higgins, N. J., Parkinson, M. and Clynes, M. 2004. Expression and prognostic relevance of Mcl-1 in breast cancer. Anticancer Res. 24: 473-482. [Medline]

16. Ohmori, K., Kawarai, S., Yasuda, N., Tanaka, A., Matsuda, H., Nishimura, R., Sasaki, N., Tsujimoto, H. and Masuda, K. 2008. Identification of c-kit mutations-independent neoplastic cell proliferation of canine mast cells. Vet. Immunol. Immunopathol. 126: 43-53. [Medline] [CrossRef]

17. Opferman, J. T., Letai, A., Beard, C., Sorcinelli, M. D., Ong, C. C. and Korsmeyer, S. J. 2003. Development and maintenance of $\mathrm{B}$ and T lymphocytes requires antiapoptotic MCL-1. Nature 426: 671-676. [Medline] [CrossRef]

18. Shigemasa, K., Katoh, O., Shiroyama, Y., Mihara, S., Mukai, K., Nagai, N. and Ohama, K. 2002. Increased MCL-1 expression is associated with poor prognosis in ovarian carcinomas. Jpn. J. Cancer Res. 93: 542-550. [Medline] [CrossRef]

19. Stam, R. W., Den Boer, M. L., Schneider, P., de Boer, J., Hagelstein, J., Valsecchi, M. G., de Lorenzo, P., Sallan, S. E., Brady, H. J., Armstrong, S. A. and Pieters, R. 2010. Association of high-level MCL-1 expression with in vitro and in vivo prednisone resistance in MLL-rearranged infant acute lymphoblastic leukemia. Blood 115: 1018-1025. [Medline] [CrossRef]

20. Strasser, A. 2005. The role of BH3-only proteins in the immune system. Nat. Rev. Immunol. 5: 189-200. [Medline] [CrossRef]

21. Tanaka, A., Konno, M., Muto, S., Kambe, N., Morii, E., Nakahata, T., Itai, A. and Matsuda, H. 2005. A novel NF-kappaB inhibitor, IMD-0354, suppresses neoplastic proliferation of human mast cells with constitutively activated c-kit receptors. Blood 105: 2324-2331. [Medline] [CrossRef]

22. Vlahos, C. J., Matter, W. F., Hui, K. Y. and Brown, R. F. 1994. A specific inhibitor of phosphatidylinositol 3-kinase, 2-(4-morpholinyl)-8-phenyl-4H-1-benzopyran-4-one (LY294002). J. Biol. Chem. 269: 5241-5248. [Medline]

23. Wertz, I. E., Kusam, S., Lam, C., Okamoto, T., Sandoval, W., Anderson, D. J., Helgason, E., Ernst, J. A., Eby, M., Liu, J., Belmont, L. D., Kaminker, J. S., O’Rourke, K. M., Pujara, K., Kohli, P. B., Johnson, A. R., Chiu, M. L., Lill, J. R., Jackson, P. K., Fairbrother, W. J., Seshagiri, S., Ludlam, M. J., Leong, K. G., Dueber, E. C., Maecker, H., Huang, D. C. and Dixit, V. M. 2011. Sensitivity to antitubulin chemotherapeutics is regulated by MCL1 and FBW7. Nature 471: 110-114. [Medline] [CrossRef]

24. Zhou, P., Qian, L., Kozopas, K. M. and Craig, R. W. 1997. Mcl1, a Bcl-2 family member, delays the death of hematopoietic cells under a variety of apoptosis-inducing conditions. Blood 89: 630-643. [Medline]

25. Zhou, P., Qian, L., Bieszczad, C. K., Noelle, R., Binder, M., Levy, N. B. and Craig, R. W. 1998. Mcl-1 in transgenic mice promotes survival in a spectrum of hematopoietic cell types and immortalization in the myeloid lineage. Blood 92: 3226-3239. [Medline] 